\title{
Comunicação e políticas
}

0 tema da influência das mídias na política é um dos marcos fundacionais das teorias da comunicação. De modo frequente, pesquisadores/as da área debruçam-se sobre as estratégias de publicização de mensagens e ideias propriamente políticas em cenários eleitorais, debates públicos, projetos de lei, manifestações populares e reivindicações diversas. Recentemente, as manifestações públicas iniciadas pelas campanhas contra os aumentos de passagens de ônibus em diversas cidades reforçaram as ligações entre a sociedade civil e 0 aparato midiático através do qual as ideias circulam. Nesse caso específico, a força das redes sociais e os embates em torno dos discursos oficiais da imprensa tradicional moldam um plano de fundo sobre 0 qual intensos debates sobre o papel das comunicações na sociedade são continuamente problematizados e valorizados.

Nesta edição, publicamos artigos que abordam diversos temas relacionados à política. Não por acaso, o tema "jornalismo e eleições" percorre os três primeiros textos, mobilizando debates sobre as últimas eleições (2010 e 2012). Afonso de Albuquerque discute o modo como entrevistadores/as do Jornal Nacional reivindicam sua posição como representantes do interesse público na primeira rodada de entrevistas transmitidas pelo telejornal durante o pleito de 2010. No texto intitulado "Em 
nome do público: jornalismo e política nas entrevistas dos presidenciáveis ao Jornal Nacional", o autor relaciona a conduta de entrevistadores/as com a concepção liberal clássica do jornalismo como "Fourth Estate". Da TV para o jornal impresso, 0 artigo "Partidarismo e ficções jornalísticas: a imprensa na eleição presidencial de 2010", de Jackson Ferreira de Alencar, analisa a cobertura do jornal Folha de S. Paulo na mesma eleição presidencial de 2010, destacando que, apesar de declarar-se como neutro, objetivo e pluralista, o jornal fez uma evidente opção partidária a favor do candidato José Serra e contra a então candidata Dilma Rousseff. Carlos D'Andrea e Isabela Campanha Careta deslocam suas atenções para as eleições para prefeito de 2012 em Belo Horizonte e Vitória, comparando as estratégias desenvolvidas em ambas as cidades. Intitulado "Agendamento intermidiático nas eleições 2012: relações entre redes sociais online e webjornais regionais em duas capitais brasileiras", 0 artigo analisa a cobertura dos webjornais regionais EM.com. br e Gazeta Online e postagens dos perfis oficiais de candidatos, apresentando as principais tendências do agendamento intermidiático nas campanhas das duas capitais.

Se nos três primeiros textos observamos uma forte continuidade temática em torno do consagrado tema do jornalismo em processos eleitorais, os artigos subsequentes desse dossiê desvelam caminhos variados sobre 0 amplo tema da comunicação e política. Em "Deslizes morais na cena midiática: reprodução da intolerância ou oportunidade para novas gramáticas morais?", Regiane Lucas Garcêz e Danila Gentil Rodriguez Cal analisam a repercussão, na Internet, de 
dois artigos: um sobre o movimento gay, de J.R. Guzzo, publicado na revista Veja, e outro sobre os Guarani Kaiowá, publicado por Walter Navarro na versão on-line do jornal 0 Tempo. No texto, buscam responder qual o papel desses "deslizes morais" na ampliação das relações de reconhecimento e na transformação das gramáticas morais que regem a sociedade.

0 artigo "Pontos de Cultura enquanto movimento social: uma pesquisa netnográfica", assinado por Julio César Pedroso e Carlos José Martins, analisa o papel dos pontos de cultura como agentes de política pública, investigando os debates em uma lista de e-mails realizado por diversos agentes de pontos de cultura do estado de São Paulo. A partir das análises realizadas, concluem que a rede dos pontos de cultura comporta um potencial significativo de catalisação de movimentos sociais em fase de expansão.

Desenvolvendo um debate de cunho mais metodológico, Fabro Steibel e Milena Marinkova questionam a suposição de que as análises de conteúdo com base em métodos quantitativos e qualitativos pode ser tomada como livre de problemas. Em "Positive, negative or neutral? The 'appraisal' variable in content analysis studies of the media", são analisados os resultados de projeto financiado pela Agência dos Direitos Fundamentais da União Europeia relativo à cobertura dos migrantes e minorias na imprensa do Reino Unido, apontando que a leitura de tais resultados quantitativos e qualitativos causa lacunas e inconsistências ao transpor resultados de um paradigma para outro. 
Esta edição conta ainda com uma resenha do livro "Do Meb à Web: o rádio na educação", de Nelson Pretto e Sandra P. Tosta, escrita por Viviam Lacerda de Souza, na qual articula as noções de educação e cidadania ao caráter educativo do rádio. Finalizando esta edição, publicamos uma entrevista exclusiva com Lawrence Grossberg concedida a Adriana Braga, na qual este autor, um dos maiores expoentes dos Estudos Culturais norte-americanos, atualiza o debate e a pertinência da perspectiva dos estudos culturais no contexto atual.

Esta edição marca a despedida do colega Felipe Trotta de nossa comissão editorial. Agradecemos imensamente sua importante contribuição para o constante aprimoramento da revista e desejamos boa sorte nos seus próximos projetos. Saudamos ainda a colega Cristiane Freitas, que assume a partir da próxima edição, junto com Adriana Braga, a comissão editorial da Revista E-Compós.

Boa leitura! 